\title{
PRODUCTIVE SUSTAINABILITY IN A SILVOPASTORAL SYSTEM
}

\author{
SUSTENTABILIDADE PRODUTIVA EM SISTEMA SILVIPASTORIL
}

\section{Wolff Camargo MARQUES FILHO'; Giselle Feliciani BARBOSA ${ }^{2}$; Deisy Lucia CARDOSO; André Dominghetti FERREIRA ${ }^{4,5}$; Denise Renata PEDRINHO ${ }^{5}$; José Antonio Maior BONO ${ }^{5}$; Celso Correa de SOUZA ${ }^{5}$; Daniel Massen FRAINER ${ }^{5,6}$}

1. Ph.D Professor, Federal Institute of the Northern Minas Gerais (IFNMG), Salinas, MG, Brazil, wolffcmf@gmail.com; 2. Ph.D Professor, State University of Mato Grosso do Sul (UEMS), Cassilândia, MS, Brazil; 3. Ph.D Professor, UEMS, Aquidauana, MS, Brazil; 4. Ph.D, Embrapa Gado de Corte, Campo Grande, MS, Brazil; 5. Ph.D Professor, Anhanguera Uniderp University, Campo Grande, MS, Brazil; 6. Ph.D Professor, UEMS, Dourados, MS, Brazil.

\begin{abstract}
The objective was to analyze the productive and economic sustainability of the silvopastoral system, in the state of Mato Grosso do Sul. The system had been implanted five years earlier, using Eucalyptus sp. (GG100), arranged in stands with three rows in an East/West direction, 20 meters apart, with 1.2 meters between plants and 1.5 meters between rows. The eucalyptus trees were planted in consortium with Brachiaria brizantha cv. Marandu and Nelore heifers, in the rearing (post-weaning) phase, weighing $186.2 \mathrm{Kg}( \pm 21.18)$ and aged approximately 12 months. Samples were collected for chemical evaluation of the soil, determination of the quantity of carbon fixed by the tree species, evaluation of the forest component, study of the animals' grazing behavior, measurement of the physiological and behavioral indicators of stress in the heifers, meteorological monitoring, analysis of animal yield and economic viability. There were improvements in the content of soil organic matter in the surface layer of the soil ( 0 to $10 \mathrm{~cm})$ and a tendency for the soil organic matter content to rise as distance from the rank of trees increased. The central rows of each stand showed less growth in height and diameter, when compared to the outer rows. There were significant differences for the mass of dry matter from leaves, branches, stem and roots between the different rows in the stand. In general, these values were higher in the lowest row, indicating that in arrangements with three rows, the central row tends to present lower development in relation to the side rows, reflecting negatively on the volume of wood and yield. The capacity for neutralizing greenhouse gases emitted by cattle was influenced by the position of the trees in the stands, and there were differences in the carbon content between the different compartments of the trees. Plasmatic concentrations of cortisol and progesterone were measured and associated with the interval in the day when animals grazed most, between $10.00 \mathrm{~h}$ and $16.00 \mathrm{~h}$. This indicated that the thermal comfort provided in the site by the system was favorable to ingestion at the time of greatest sunshine, as well as resulting in less total time spent on ingestion compared to what is seen in other production systems for cattle in extensive pastures. The financial balance for the silvopastoral activities carried out on the property revealed, in general, greater return rate for the forestry compared to cattle in the system, so far.
\end{abstract} comfort.

KEYWORDS: Eucalyptus sp.. Agroforestry systems. Carbon fixing. Beef cattle. Animal welfare. Thermal

\section{INTRODUCTION}

Climate change, observed throughout the world, is increasingly being linked to aggressions against nature. Among these are the excess of methane, produced by agricultural sources, the burning of biomass and fossil fuels and the fermentative processes taking place when ruminants are farmed; the latter eliminate about $15 \%$ of the methane in the atmosphere (WUEBBLES; HAYHOE, 2002).

There is growing demand from the consumer market to provide higher quality products obtained in an environmentally friendly manner. This is associated with a low yield from extensive livestock farming, in Brazil generally, and means of production are needed that generate a lower environmental impact and greater profit in smaller spaces. This is characterized by sustainable livestock farming, as seen in the silvopastoral system (ALBRECHT; KANDJI, 2003)

This system is a modality based on agroforestry principles for the management of natural resources, where trees or shrubs, forage plants and animals are placed together. In addition, animals raised in this system have a lower risk of thermal stress due to shadow arising from afforestation, favoring conditions animal to express their genetic potential and the welfare (DIAS FILHO, 2005). A reduction in the effects of gases generated during this type of productive system is observed in the significant production of forage matter by grasses, by the accumulation of organic matter in the soil, by substantial carbon capture and mitigation of greenhouse gas emissions (GHG), culminating in the greater efficiency of land use (PRIMAVESI et al., 2007; TORRES et al., 2014). 
In terms of implementation, this is an alternative investment, justified by the predictability of future economic benefits that outweigh conventional cattle systems (BROOM et al., 2013). In this case, the study of economic viability has not been carried out, and an intuitive analysis of the undertaking prevails, revealing a level of uncertainty in decision-making. In this situation, the issue of viability in livestock farming involves the same uncertainties as found in other investments. When taking a decision, a question should be asked: what would be the feasible investment alternatives and what would their returns likely be? To this end, real data on the costs and returns should be analyzed (PINDYCK; RUBENSFIELD, 2013). However, these aspects have so far ignored the aggregated value of the products and the expansion of the consumer market that can be seen in sustainable development.

Therefore, the objective was to carry out a chemical evaluation of the soil, determination of the quantity of carbon fixed by the tree species, evaluation of the forest component, study of the animals' grazing behavior, measurement of the physiological and behavioral indicators of stress in the heifers, meteorological monitoring, analysis of animal yield and economic viability of the silvipastoral system.

\section{MATERIAL AND METHODS}

The study was carried out between January and April of 2015, on 120 hectares of silvopastoral system in Bandeirantes, Mato Grosso do Sul state,

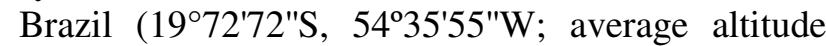
$630 \mathrm{~m})$. The climate, according to the Köppen (1948) classification system, is Aw, tropical climate with dry winter. Average annual climatic variables are: rainfall $1275 \mathrm{~mm}$ and temperature $23.1^{\circ} \mathrm{C}$. The system had been implemented in 2009, using Eucalyptus urograndis (Eucalyptus urophylla $\mathrm{x}$ Eucalyptus grandis) clone (GG100), arranged homogeneously in stands with three rows in an East/West direction, 20 meters apart, with 1.2 meters between plants and 1.5 meters between rows. The eucalyptus trees were planted in consortium with Brachiaria brizantha cv. BRS Marandu and Nelore heifers in the rearing phase, weighing 186.2 $\mathrm{Kg}( \pm 21.18)$ and aged approximately 12 months, submitted to extensive grazing with a mineral supplement and water ad libitum.

Meteorological evaluation was carried out daily, by installing a digital thermometer for maximum and minimum temperature, rainfall and relative humidity measurement, in the middle of the pasture.

Fifty nelore heifers was selected randomly from the 136 animals that composed the lot for the evaluantions. Animal performance was determined by weighing all the lot each month during the experimental period. Having identified the 15 animals selected by marking them bilaterally, in the region of the rump and back with red Topmarker ${ }^{\circledR}$ spray paint, their behavior was evaluated monthly to determine the period spent to pasture, mode of pasture, mean time spent at rest and in rumination, frequency of defecation and micturition by means of observation for eight hours in the pasture. This was carried out by trained evaluators, who remained far from the animals, on horseback and equipped with binoculars, radio-communicator and a clipboard for taking notes. Animal welfare and sexual precocity were measured from blood samples taken monthly by venipuncture of the jugular, using Vacutainer $^{\circledR}$ needles and glass tubes of $10 \mathrm{~mL}$, which were centrifuged at $3000 \mathrm{G}$ for 15 minutes. The plasma was stored in Eppendorf ${ }^{\circledR}$ microtubes of $1.5 \mathrm{~mL}$ for later determination of the plasmatic concentration of cortisol and progesterone by radioimmunoassay, commercial kit Cortisol Immunotech Genese ${ }^{\circledR}$, and Progesterone Immunotech Genese ${ }^{\circledR}$, respectively.

For the chemical evaluation of the soil were carried out the analysis of $\mathrm{pH}$ in $\mathrm{CaCl}_{2}\left(0.01 \mathrm{~mL}^{-1}\right), \mathrm{P}$ $\left(\mathrm{Melich}^{-1}\right) \mathrm{K}, \mathrm{Ca}, \mathrm{Mg}, \mathrm{Al}, \mathrm{H}$, organic matter (OM) (CLAESSEN, 1997), at the layers of 0 to 10,10 to 20 and 20 to $40 \mathrm{~cm}$ of depth from the surface, from samples at 2.5, 5.0, 7.5 and $10 \mathrm{~m}$ distance from the line of planting of the eucalyptus, in the direction of the next stand. The results were compared with samples collected in conventional grazing system, on the same property, with the same pasture $(B$. brizantha cv. BRS Marandu), formation period, pasture management and stocking rate, however, without the presence of the tree component.

The height of the trees was determined using a clinometer, and the diameter at breast height (DBH) with calipers, which allowed the calculation of volume per plant and the volume of wood per hectare (PORFÍRIO DA SILVA et al., 2009). From 21 selected trees, there was the collection of branches, leaves, stems and roots, removed to determine the length, green weight, dry weight and carbon content using a $\mathrm{CN}$ auto-analyzer (Leco $\mathrm{CN}$ 628) (KANDA et al. 2004). For the transformation of $\mathrm{C}\left(\mathrm{t} . \mathrm{ha}^{-1}\right)$ into $\mathrm{CO}_{2} \mathrm{eq}$, was used the conversion factor of 3.67, and for determining the ability of forest component to neutralize the greenhouse gases emitted by cattle, it was considered that one $\mathrm{AU}$ emits $1,88 \mathrm{t} \mathrm{CO}_{2} \mathrm{eq}$. According to the methodology 
proposed by the IPCC (2006), only the carbon fixed by the stems is considered to calculate the potential neutralization of GHG emissions.

The economic viability was obtained by analyzing the returns, costs, net profit, investment made and rate of return on investment (ROI) from 2011 to 2014, from the formula below:

$$
\text { ROI }=\left(\frac{\text { Gain obtained }}{\text { Amount spent }}-1\right) \times 100(\%)
$$

The data were submitted to statistical analysis of variance, and the means were compared by the Tukey test and Scott-Knott test $(p \leq 0.01$ and $p \leq 0.05)$.

\section{RESULTS AND DISCUSSION}

The meteorological data are illustrated in Table 1. It should be noted that they are characteristic of the tropical summer in the Brazilian Mid-West; however, with the occurrence of a lower rainfall in this year in January. The mean precipitation over the four months was $175.75 \mathrm{~mm}$.

Table 1. Averages of evaluations climatics - relative humidity, minimum and maximum ar temperatures and pluviometric index - , in addition of the total means ( \pm standard deviation) during the collection period and productive diagnosis in Silvopastoral System. Bandeirantes, Mato Grosso do Sul, Brazil, 2015.

\begin{tabular}{lcccc}
\hline $\begin{array}{l}\text { Months/ } \\
\text { Climate Data }\end{array}$ & $\begin{array}{c}\text { Ar Relative } \\
\text { Humidity } \\
(\mathbf{\%})\end{array}$ & $\begin{array}{c}\text { Minimum } \\
\text { Temperature } \\
\left({ }^{\mathbf{O}} \mathbf{C}\right)\end{array}$ & $\begin{array}{c}\text { Maximum } \\
\text { Temperature } \\
\left({ }^{\mathbf{0}} \mathbf{C}\right)\end{array}$ & $\begin{array}{c}\text { Pluviometric } \\
\text { Index (mm/day) }\end{array}$ \\
\hline January & 0.46 & 19.57 & 37.05 & 3.63 \\
February & 0.55 & 19.84 & 36.16 & 11.42 \\
March & 0.59 & 19.64 & 35.26 & 4.26 \\
April & 0.68 & 19.83 & 36.18 & 3.10 \\
\hline Average $( \pm$ SD) & $0.57( \pm 0.08)$ & $19.72( \pm 0.13)$ & $36.16( \pm 0.73)$ & $5.60( \pm 3.90)$ \\
\hline
\end{tabular}

When the characteristics of the soil from the conventional and the silvopastoral/beef production systems are compared, at the layers from 10 to $20 \mathrm{~cm}$ and 20 to $40 \mathrm{~cm}$, no alterations were seen in fertility (Table 2). From 0 to $10 \mathrm{~cm}$ below the surface, there were improvements in the content of soil organic matter, when the single pasture system (Conventional System) was compared with the integrated system (Silvopastoral System), with a tendency for organic matter to rise as the distance from the eucalyptus rows increased, probably because, in natural shading conditions, are observed increases in organic matter degradation of plant residues. The $\mathrm{pH}$ in $\mathrm{CaCl}_{2}$ was higher in the conventional system, but no difference was seen between the systems, which may be linked to the calcium, which had higher values than in the integrated system. P was the only nutrient that did not present a difference between systems. At the topsoil, $\mathrm{K}$ at $10.0 \mathrm{~m}$ from the row of eucalyptus and $\mathrm{Mg}$ at $10 \mathrm{~m}$ and $7.5 \mathrm{~m}$, there were higher contents than at other sampling points and in the single pasture.

The data for the forest component are in Tables 3, 4, 5 and 6, and these show the influence of the position of the tree in the stand, with the plants in the central row presenting less development than the side rows. As explained by
Bernardo (1995) and Oliveira et al. (2009), this was occasioned by the competition between individuals for water, nutrients and light, as well as the spacing used in this specific arrangement of the silvopastoral system. According to Santos (2011) and Benin (2014), the growth in height and diameter of the eucalyptus trees was directly proportional to the increase in the spacing between plants.

However, the trees in the lowest position showed the highest values for $\mathrm{DBH}$, volume of wood per tree and volume of wood per hectare in relation to the trees in other positions. This may be related to the fact that trees in this position received more light, since they were facing north. Greater exposure to the sun's rays leads to greater production of photoassimilates by the plants, thus yielding greater growth.

The characteristic of volume of wood per plant is strongly influenced by the characteristics height and DBH. Volume of wood per hectare presented the same tendency as volume of wood per tree, demonstrating that the larger the useful area per plant and the greater the light received by the plants, the greater the yield of wood, as confirmed by Magalhães et al. (2006), which proves that the competition between the plants may cause negative effect on yield. 
Table 2. Averages of organic matter, $\mathrm{pH}$ and soil macronutrients in areas with pasture of Brachiaria brizantha cv. Marandu in Conventional System and associated with eucalypt in Silvopastoral System. Bandeirantes, Mato Grosso do Sul, Brazil, 2015.

\begin{tabular}{|c|c|c|c|c|c|c|c|}
\hline \multirow{3}{*}{ Treatments } & OM & pH & $\mathbf{P}$ & $\mathbf{K}$ & $\mathbf{C a}$ & Mg & $\mathrm{S}_{\text {-SO4 }}$ \\
\hline & g.dm ${ }^{-3}$ & $\mathrm{CaCl}_{2}$ & \multicolumn{2}{|c|}{$\mathrm{mg} \cdot \mathrm{dm}^{-3}$} & \multicolumn{2}{|c|}{ mmol.dm ${ }^{-3}$} & mg.dm ${ }^{-3}$ \\
\hline & \multicolumn{7}{|c|}{0 to $10 \mathrm{~cm}$} \\
\hline Conventional System & $13.80^{\mathrm{b}}$ & $4.63^{\mathrm{a}}$ & $3.00^{\mathrm{a}}$ & $14.00^{\mathrm{c}}$ & $10.10^{\mathrm{a}}$ & $2.70^{c}$ & $3.10^{\mathrm{ab}}$ \\
\hline $2.5 \mathrm{~m}$ & $17.60^{\mathrm{a}}$ & $4.24^{\mathrm{a}}$ & $2.30^{\mathrm{a}}$ & $26.00^{\mathrm{b}}$ & $5.59^{\mathrm{b}}$ & $3.70^{\mathrm{bc}}$ & $4.03^{\mathrm{a}}$ \\
\hline $5.0 \mathrm{~m}$ & $17.90^{\mathrm{a}}$ & $4.27^{\mathrm{a}}$ & $3.20^{\mathrm{a}}$ & $17.00^{\mathrm{c}}$ & $4.86^{\mathrm{b}}$ & $4.00^{\mathrm{b}}$ & $2.53^{\mathrm{b}}$ \\
\hline $7.5 \mathrm{~m}$ & $17.90^{\mathrm{a}}$ & $4.38^{\mathrm{a}}$ & $3.50^{\mathrm{a}}$ & $16.00^{\mathrm{c}}$ & $6.19^{\mathrm{b}}$ & $5.00^{\mathrm{a}}$ & $2.84^{\mathrm{a}}$ \\
\hline \multirow[t]{2}{*}{$10.0 \mathrm{~m}$} & $19.00^{\mathrm{a}}$ & $4.40^{\mathrm{a}}$ & $3.50^{\mathrm{a}}$ & $33.00^{\mathrm{a}}$ & $6.73^{\mathrm{b}}$ & $5.20^{\mathrm{a}}$ & $5.67^{\mathrm{a}}$ \\
\hline & \multicolumn{7}{|c|}{10 to $20 \mathrm{~cm}$} \\
\hline Conventional System & $12.60^{\mathrm{a}}$ & $4.58^{\mathrm{a}}$ & $2.90^{\mathrm{a}}$ & $14.00^{\mathrm{a}}$ & $8.06^{\mathrm{a}}$ & $2.60^{\mathrm{a}}$ & $3.49^{\mathrm{a}}$ \\
\hline $2.5 \mathrm{~m}$ & $13.70^{\mathrm{a}}$ & $4.14^{\mathrm{a}}$ & $2.10^{\mathrm{a}}$ & $12.00^{\mathrm{a}}$ & $2.41^{\mathrm{b}}$ & $1.70^{\mathrm{a}}$ & $2.94^{\mathrm{a}}$ \\
\hline $5.0 \mathrm{~m}$ & $13.70^{\mathrm{a}}$ & $4.18^{\mathrm{a}}$ & $2.10^{\mathrm{a}}$ & $13.00^{\mathrm{a}}$ & $3.27^{\mathrm{b}}$ & $1.90^{\mathrm{a}}$ & $2.89^{\mathrm{a}}$ \\
\hline $7.5 \mathrm{~m}$ & $14.40^{\mathrm{a}}$ & $4.21^{\mathrm{a}}$ & $2.50^{\mathrm{a}}$ & $14.00^{\mathrm{a}}$ & $3.29^{\mathrm{b}}$ & $2.10^{\mathrm{a}}$ & $2.74^{\mathrm{a}}$ \\
\hline \multirow[t]{2}{*}{$10.0 \mathrm{~m}$} & $13.80^{\mathrm{a}}$ & $4.22^{\mathrm{a}}$ & $2.20^{\mathrm{a}}$ & $14.00^{\mathrm{a}}$ & $3.30^{\mathrm{b}}$ & $2.00^{\mathrm{a}}$ & $3.20^{\mathrm{a}}$ \\
\hline & \multicolumn{7}{|c|}{20 to $40 \mathrm{~cm}$} \\
\hline Conventional System & $11.60^{\mathrm{a}}$ & $4.45^{\mathrm{a}}$ & $1.50^{\mathrm{a}}$ & $15.00^{\mathrm{a}}$ & $5.89^{\mathrm{a}}$ & $2.20^{\mathrm{a}}$ & $3.75^{\mathrm{a}}$ \\
\hline $2.5 \mathrm{~m}$ & $10.40^{\mathrm{a}}$ & $4.14^{\mathrm{a}}$ & $1.60^{\mathrm{a}}$ & $11.00^{\mathrm{a}}$ & $2.16^{\mathrm{b}}$ & $1.20^{\mathrm{a}}$ & $4.24^{\mathrm{a}}$ \\
\hline $5.0 \mathrm{~m}$ & $9.80^{\mathrm{a}}$ & $4.16^{\mathrm{a}}$ & $1.40^{\mathrm{a}}$ & $10.00^{\mathrm{a}}$ & $2.28^{\mathrm{b}}$ & $1.20^{\mathrm{a}}$ & $4.13^{\mathrm{a}}$ \\
\hline $7.5 \mathrm{~m}$ & $10.40^{\mathrm{a}}$ & $4.23^{\mathrm{a}}$ & $1.30^{\mathrm{a}}$ & $10.00^{\mathrm{a}}$ & $2.81^{\mathrm{b}}$ & $1.60^{\mathrm{a}}$ & $3.77^{\mathrm{a}}$ \\
\hline $10.0 \mathrm{~m}$ & $9.40^{\mathrm{a}}$ & $4.20^{\mathrm{a}}$ & $1.30^{\mathrm{a}}$ & $14.00^{\mathrm{a}}$ & $2.74^{\mathrm{b}}$ & $1.50^{\mathrm{a}}$ & $3.78^{\mathrm{a}}$ \\
\hline
\end{tabular}

Means followed by the same letters in columns and to the same depth do not differ (Tukey test, $p \leq 0.05$ ).

Table 3. Averages of total height, diameter at breast height (DBH), wood volume per plant and per hectare of Eucalyptus sp. (GG100) in Silvopastoral System. Bandeirantes, Mato Grosso do Sul, Brazil, 2015.

\begin{tabular}{lcccc}
\hline Rows & $\begin{array}{c}\text { Total Height } \\
(\mathbf{m})\end{array}$ & $\begin{array}{c}\text { DBH } \\
(\mathbf{c m})\end{array}$ & $\begin{array}{c}\text { Volume/tree } \\
\left(\mathbf{m}^{\mathbf{3}}\right)\end{array}$ & $\begin{array}{c}\text { Volume/ha } \\
\left(\mathbf{m}^{\mathbf{3}}\right)\end{array}$ \\
\hline Upper Row (South) & $23.00^{\mathrm{a}}$ & $15.00^{\mathrm{b}}$ & $0.19^{\mathrm{b}}$ & $68.78^{\mathrm{b}}$ \\
Central Row & $19.50^{\mathrm{b}}$ & $11.90^{\mathrm{c}}$ & $0.10^{\mathrm{c}}$ & $36.20^{\mathrm{c}}$ \\
Below Row (North) & $23.40^{\mathrm{a}}$ & $15.90^{\mathrm{a}}$ & $0.21^{\mathrm{a}}$ & $76.02^{\mathrm{a}}$ \\
\hline CV (\%) & 7.81 & 5.59 & 15.64 & 15.28 \\
Average & 22.00 & 14.30 & 0.17 & 60.33 \\
\hline
\end{tabular}

Means followed by the same letters in columns do not differ (Scott-Knott test, $p \leq 0.01$ ).

Table 4. Averages of dry matter mass of leaves, branches, stems and roots of Eucalyptus sp. (GG100) in Silvopastoral System. Bandeirantes, Mato Grosso do Sul, Brazil, 2015.

\begin{tabular}{lcccc}
\hline \multirow{2}{*}{ Rows } & \multicolumn{4}{c}{ Dry matter mass (t.ha') } \\
\cline { 2 - 5 } & Leaves & Branches & Stems & Roots \\
\hline Upper Row (South) & $1.40^{\mathrm{b}}$ & $1.52^{\mathrm{b}}$ & $39.75^{\mathrm{b}}$ & $5.32^{\mathrm{b}}$ \\
Central Row & $0.86^{\mathrm{c}}$ & $0.83^{\mathrm{b}}$ & $18.26^{\mathrm{c}}$ & $2.24^{\mathrm{c}}$ \\
Below Row (North) & $2.07^{\mathrm{a}}$ & $2.68^{\mathrm{a}}$ & $53.26^{\mathrm{a}}$ & $7.71^{\mathrm{a}}$ \\
\hline CV $(\%)$ & 13.14 & 17.64 & 7.29 & 9.75 \\
Average & 0.73 & 1.67 & 37.03 & 5.07 \\
\hline
\end{tabular}

Means followed by the same letters in columns do not differ (Scott-Knott test, $p \leq 0.01$ ). 
Table 5. Averages of stems carbon contents $(\mathrm{CC}-\%)$, of carbon contents per hectare $\left(\mathrm{C}-\mathrm{t} . \mathrm{ha}^{-1}\right), \mathrm{of}_{\mathrm{CO}} \mathrm{CO}_{2}\left(\mathrm{t} . \mathrm{ha}^{-1}\right)$ and potential of neutralize the greenhouse gas emissions for cattle (PNEC - AU.ha ${ }^{-1}$ ), according to each row of the eucalypt tree component, accumulated to 72 months after planting, in the Silvopastoral System. Bandeirantes, Mato Grosso do Sul, Brazil, 2015.

\begin{tabular}{|c|c|c|c|c|}
\hline Rows & $\mathrm{CC}(\%)$ & $\mathrm{C}\left(\mathrm{t}_{\mathrm{h}} \mathrm{ha}^{-1}\right)$ & $\mathrm{CO}_{2} \mathrm{eq}\left(\right.$ t.ha $\left.^{-1}\right)$ & PNEC (AU.ha' $\left.{ }^{-1}\right)$ \\
\hline Upper Row (South) & $47.5^{\mathrm{a}}$ & $18.9^{\mathrm{b}}$ & $67.9^{b}$ & $36.1^{\mathrm{b}}$ \\
\hline Central Row & $47.3^{\mathrm{a}}$ & $8.6^{\mathrm{c}}$ & $31.0^{\mathrm{c}}$ & $16.5^{\mathrm{c}}$ \\
\hline Below Row (North) & $47.4^{\mathrm{a}}$ & $25.2^{\mathrm{a}}$ & $90.8^{\mathrm{a}}$ & $48.3^{\mathrm{a}}$ \\
\hline $\mathrm{CV}(\%)$ & 0.40 & 7.13 & 7.13 & 7.13 \\
\hline Average & 47.4 & 17.6 & 63.2 & 33.6 \\
\hline
\end{tabular}

AU: an adult cattle $(450 \mathrm{Kg})$. Means followed by the same letters in columns do not differ (Scott-Knott test, $p \leq 0.01)$.

Table 6. Averages of stems carbon contents $(\mathrm{CC}-\%)$, of carbon contents per hectare $\left(\mathrm{C}-\mathrm{t} . \mathrm{ha}^{-1}\right), \mathrm{of}_{\mathrm{CO}} \mathrm{eq}^{\left(\mathrm{t} . h \mathrm{ha}^{-1}\right)}$ and potential of neutralize the greenhouse gas emissions for cattle (PNEC - AU.ha ${ }^{-1}$ ), according to each parts of the eucalypt tree component, accumulated to 72 months after planting, in the Silvopastoral System. Bandeirantes, Mato Grosso do Sul, Brazil, 2015.

\begin{tabular}{lcccc}
\hline Parts of the tree & $\mathbf{C C}(\%)$ & $\mathbf{C}\left(\mathbf{t} . \mathbf{h a}^{-\mathbf{1}}\right)$ & $\mathbf{C O}_{\mathbf{2}} \mathbf{e q}\left(\mathbf{t} . \mathbf{h a}^{\mathbf{- 1}}\right)$ & PNEC $\left(\mathbf{A U} \cdot \mathbf{h a}^{\mathbf{- 1}}\right)$ \\
\hline Stems & $47.4^{\mathrm{b}}$ & $12.6^{\mathrm{a}}$ & $63.2^{\mathrm{a}}$ & $33.6^{\mathrm{a}}$ \\
Leaves & $49.9^{\mathrm{a}}$ & $0.7^{\mathrm{c}}$ & $2.6^{\mathrm{c}}$ & $1.4^{\mathrm{c}}$ \\
Roots & $47.7^{\mathrm{b}}$ & $2.4^{\mathrm{b}}$ & $8.8^{\mathrm{b}}$ & $4.7^{\mathrm{b}}$ \\
Branches & $46.9^{\mathrm{c}}$ & $0.8^{\mathrm{c}}$ & $2.8^{\mathrm{c}}$ & $1.5^{\mathrm{c}}$ \\
\hline CV $(\%)$ & 1.26 & 45.30 & 45.30 & 45.30 \\
Average & 48.0 & 5.4 & 19.4 & 10.3 \\
\hline
\end{tabular}

AU: an adult cattle $(450 \mathrm{Kg})$. Means followed by the same letters in columns do not differ (Scott-Knott test, $p \leq 0.01)$.

It was also noted that the dry mass of the different components of the trees was closely linked, so that the greater the dry mass of the aerial part, the greater the dry mass of the root system. The quantification of the dry mass of the plants also allows an inference that the plants in lower rows have a greater potential for nutrient cycling by means of leaf litter. According to Cunha et al. (2005), the leaf is the component that most contributes to nutrient deposit in the soil, helping to maintain soil fertility. It is fundamental to quantify dry mass to determine the quantity of carbon accumulated in the plants, as well as the various benefits provided by the forest component in an integrated system. Indeed, impacts on microclimatic variables and carbon capture broaden the possibilities for use in situations of microclimate change (NEVES et al., 2004).

The greatest accumulation of carbon was seen in the plants situated in the lower rows, and therefore their capacity to mitigate the effects of greenhouse gases (GHG) emitted by cattle was greater. The trees in the upper rows presented intermediate values, and the trees in the central rows had a lower capacity to mitigate GHG. Among trees in the upper rows, 3.2 t.ha $^{-1}$.year-1 of $\mathrm{C}$ was fixed, which corresponds to 11.3 t.ha $^{-1}$.year ${ }^{-1}$ of $\mathrm{CO}_{2}$ eq., equivalent to neutralizing the emission of 6.0 AU.ha ${ }^{-1}$.year ${ }^{-1}$. Considering the trees in the central rows, it was observed that the accumulation of carbon was $1.4 \mathrm{t} \mathrm{ha}^{-1}$ year ${ }^{-1}$, corresponding to 5.2 t.ha ${ }^{-1}$.year ${ }^{-1}$ of $\mathrm{CO}_{2}$ eq., equivalent to potential neutralization of GHG of $2.8 \mathrm{AU}^{-1} \mathrm{ha}^{-1} \cdot \mathrm{year}^{-1}$. The current work corroborates that of Torres et al. (2014), which reported a high capacity to neutralize GHGs emitted by cattle in silvopastoral systems.

The cattle grazing pressures in degraded pasture areas in Brazil remain, usually, below 1.0 AU.ha ${ }^{-1}$, therefore, independent of the tree position in the stand, there will be a surplus of carbon fixed by integrated systems, corroborating Neves et al. (2004), who observed a trend of recovery of original carbon stocks present in natural cerrado vegetation. Considering this silvopastoral system as a whole, it is verified potential for neutralize greenhouse gases emitted by 16.8 AU.ha ${ }^{-1}$.ano ${ }^{-1}$.

Although the carbon accumulated in the leaves, branches and roots not be counted to calculate the potential neutralization of GHGs emitted by cattle (IPCC, 2006), analysis for determining the carbon content of these component were done. The highest carbon content was found in leaves and less was found in branches. Despite this, the amount of carbon accumulated in the leaves is similar to the amount accumulated in the branches, and less than the other components.

The mean weight in the cattle lot in the period was $206.34 \mathrm{Kg}$ ( \pm 18.91$)$, equivalent to reports in the literature in a similar system with animals aged over one year (VIEIRA et al., 2006). 
Nevertheless, there was a decreased performance in weight gain during the study related to the management of trimming the central row of eucalyptus from the month of February onwards. The mean grazing time was lower than that observed in cattle submitted to conventional production systems (Table 7), but among the animals in the lot lower performance was not seen when they did not receive any protein-energy supplement. This result may be a consequence of the thermal comfort provided by the joint system, less energy expended on maintenance, greater nutritional quality in the available grass and genetic merit in the animals (THUROW et al., 2009; RODRIGUES, 2011; GERON et al., 2014). It was notable that the grazing time took place between $10.00 \mathrm{~h}$ and $16.00 \mathrm{~h}$, thus including the times with most sunshine. This is not observed in animals evaluated within an extensive grazing system (NICODEMO et al., 2004; ZANINE et al., 2006; THUROW et al., 2009; SOUZA et al., 2010).

Table 7. Averages ( \pm standard deviation) of the daily pasture period, pasture mode, average idleness time, average rumination time, frequency of defecations and urinations, during the collection period and productive diagnosis in Silvopastoral Systems. Bandeirantes, Mato Grosso do Sul, Brazil, 2015.

\begin{tabular}{|c|c|c|c|c|c|c|}
\hline Months & $\begin{array}{c}\text { Daily } \\
\text { pasture } \\
\text { period (h) }\end{array}$ & Mode of pasture & $\begin{array}{l}\text { Idleness } \\
\text { time (h) }\end{array}$ & $\begin{array}{c}\text { Rumination } \\
\text { time (h) }\end{array}$ & $\begin{array}{c}\text { Frequency } \\
\text { of } \\
\text { defecation }\end{array}$ & $\begin{array}{c}\text { Frequency } \\
\text { of } \\
\text { urination }\end{array}$ \\
\hline January & 5.30 & $\begin{array}{l}\text { In } 3 \text { lots, pasture in } \\
\text { irregular movement }\end{array}$ & 0.12 & 0.47 & 3.33 & 3.56 \\
\hline February & 5.15 & $\begin{array}{l}\text { In } 1 \text { lot, pasture in } \\
\text { constrained } \\
\text { movement }\end{array}$ & 0.09 & 0.53 & 4.86 & 4.13 \\
\hline March & 5.94 & $\begin{array}{l}\text { In } 3 \text { lots, pasture in } \\
\text { irregular movement }\end{array}$ & 0.16 & 0.35 & 3.40 & 4.21 \\
\hline $\begin{array}{l}\text { Average } \\
( \pm \mathrm{SD})\end{array}$ & $\begin{array}{c}5.46 \\
( \pm 0.41) \\
\end{array}$ & $\begin{array}{r}19.72 \\
( \pm 0.13) \\
\end{array}$ & $\begin{array}{c}0.12 \\
( \pm 0.03) \\
\end{array}$ & $\begin{array}{c}0.45 \\
( \pm 0.09) \\
\end{array}$ & $\begin{array}{c}3.86 \\
( \pm 0.86) \\
\end{array}$ & $\begin{array}{c}3.96 \\
( \pm 0.35) \\
\end{array}$ \\
\hline
\end{tabular}

The physiological indicators of stress in the experimental animals and the plasmatic concentrations of cortisol and progesterone were restricted to $6.73( \pm 2.92)$ ng. $\mathrm{mL}^{-1}$ and $0.84( \pm 0.11)$ ng. $\mathrm{mL}^{-1}$, respectively. These results illustrate the favorable situation in regard to the ideal conditions for animal welfare, as previously observed by Ribeiro et al. (2006) and Macedo et al. (2011). In adverse conditions, animals from the Nelore breed in the same phase of their life, if exposed to adverse rearing situations or stressful conditions, present higher values than those present in the heifers kept in a silvopastoral grazing system. However, this level of progesterone circulating demonstrated that none of the animals had reached puberty by the end of the blood sample collections.

The data related to economic viability (Table 8) showed a greater volatility for the return obtained with cattle farming in this period, presenting both positive and negative returns. With forestry, the values of the rates of return are more stable for the period, always presenting higher rates than cattle farming, except in 2014.

Table 8. Evolution costs $(\mathrm{R} \$)$ and revenues total $(\mathrm{R} \$)$ obtained with the animal and vegetable component in Silvopastoral System, from 2011 to 2014. Bandeirantes, Mato Grosso do Sul, Brazil, 2015.

\begin{tabular}{lcccc}
\hline Description/Year & $\mathbf{2 0 1 1}$ & $\mathbf{2 0 1 2}$ & $\mathbf{2 0 1 3}$ & $\mathbf{2 0 1 4}$ \\
\cline { 2 - 5 } & \multicolumn{2}{c}{ Animal Component } & & \\
\hline Revenues & $1,780,918$ & $2,642,434$ & $1,820,872$ & $3,130,434$ \\
Costs & $1,986,780$ & $1,839,003$ & $2,042,005$ & $2,372,417$ \\
Result & $-205,862$ & 803,431 & $-221,134$ & 758,017 \\
Return rate & $-10 \%$ & $44 \%$ & $-11 \%$ & $32 \%$ \\
\hline \multicolumn{5}{c}{ Vegetable Component } \\
\hline Revenues & 124,086 & 174,752 & 831,628 & $1,291,544$ \\
Costs & 110,649 & 106,565 & 377,741 & $1,103,469$ \\
Result & 13,437 & 68,187 & 453,887 & 188,075 \\
Return rate & $12 \%$ & $64 \%$ & $120 \%$ & $17 \%$ \\
\hline
\end{tabular}




\section{CONCLUSION}

The productive arrangement in the silvopastoral system was economically sustainable both in environmental and in productive terms.

\section{ACKNOWLEDGMENTS}

The authors acknowledge the owners, managers and employees of the Agropecuária Ouro Branco, a company of the Italian Group Brazzale, for the support and granted financial assistance for the execution of this research.

Search authorized by the Ethics Committee on Animals Use of Anhanguera Educacional Ltda.CEUA/AESA - opinion number 2978.

RESUMO: Objetivou-se analisar a sustentabilidade produtiva e econômica do Sistema Silvipastoril, em Mato Grosso do Sul, implantado há 5 anos, mediante consórcio entre Eucalyptus sp. (GG100), dispostos em renques com fileiras triplas no sentido Leste/Oeste, distantes entre si por 20 metros, com 1,2 metros entre plantas e 1,5 metros entre fileiras, Brachiaria brizantha cv. Marandu e novilhas Nelore, em fase de recria, com 186,2 $\mathrm{Kg}( \pm 21,18)$ e aproximadamente 12 meses. Foram coletadas amostras para avaliação química do solo, determinação da quantidade fixada de carbono pela espécie arbórea, avaliação do componente florestal, estudo do comportamento de pastejo dos animais, mensuração dos indicadores fisiológicos e comportamentais de estresse das novilhas, controle meteorológico, da produtividade animal e a viabilidade econômica. Houve melhorias nos teores de matéria orgânica do solo na camada superficial do solo $(0$ a $10 \mathrm{~cm})$ e uma tendência de aumento do teor de matéria orgânica no solo a medida que se distancia do renque. As fileiras centrais de cada renque tiveram menor crescimento em altura e em diâmetro, quando comparadas às fileiras laterais. Houve diferenças significativas para a massa de matéria seca de folhas, ramos, caule e raízes entre as diferentes fileiras do renque, sendo de maneira geral, maiores na fileira inferior, indicando que em arranjos com fileiras triplas, as fileiras centrais tendem a apresentar um desenvolvimento inferior em relação às fileiras laterais, o que reflete negativamente no volume de madeira e produção. A capacidade de neutralizar a emissão de GEEs por bovinos foi influenciada pela posição das árvores nos renques de plantio e houve diferenças nos teores de carbono dos diferentes compartimentos das árvores. A mensuração das concentrações plasmáticas de cortisol e de progesterona, associados ao intervalo do dia em que se observou maior frequência de pastejo pelos animais, entre 10 e 16 horas, indica que o conforto térmico proporcionado no ambiente local pelo sistema é favorável para a ingestão nos momentos de maior incidência de luz solar, bem como resultou em menor tempo de ingestão total comparado ao que se verifica nos demais sistemas de produção de bovinos em pastejo extensivo. $\mathrm{O}$ balanço financeiro das atividades silvipastoril realizadas na propriedade revelou, no geral, maior taxa de retorno à silvicultura comparada à criação de bovinos no sistema, até o momento.

PALAVRAS-CHAVES: Eucalyptus sp.. Sistemas agroflorestais. Fixação de carbono. Gado de corte. Bemestar animal. Conforto térmico.

\section{REFERENCES}

ALBRECHT, A.; KANDJI, S. T. Carbon sequestration in tropical agroforestry systems. Agriculture, Ecosystems and Enviroment, Amsterdam, v. 99, n. 1-3, p. 15-27, 2003. https://doi.org/10.1016/S01678809(03)00138-5

BENIN, C. C. Efeito do espaçamento na produção, variáveis dendrométricas e propriedades da madeira de Eucalyptus benthamii. 2014. 80 f. Dissertação (Mestrado em Engenharia Florestal), Universidade Estadual do Centro, Irati, 2014.

BERNARDO, A. L. Crescimento e eficiência nutricional de Eucalyptus spp. sob diferentes espaçamentos na região do cerrado de Minas Gerais. 1995. 102 f. Dissertação (Mestrado em Ciências Florestais), Universidade Federal de Lavras, Lavras, 1995.

BROOM, D. M.; GALINDO, F. A.; MURGUEITIO, E. Sustainable, efficient livestock production with high biodiversity and good welfare for animals. Proceedings of the Royal Biological Science, London, v. 280, p. 19, 2013. https://doi.org/10.1098/rspb.2013.2025 
CLAESSEN, M. E. C. (Org.). Manual de métodos de análise de solo. 2. ed. rev. atual. Rio de Janeiro: EMBRAPA-CNPS, 1997. 212 p. (EMBRAPA-CNPS. Documentos, 1).

CUNHA, G. M.; GAMA-RODRIGUES, A. C.; COSTA, G. S. Ciclagem de nutrientes em Eucalyptus grandis W. Hill ex Maiden no norte fluminense. Revista Árvore, Viçosa, v. 29, n. 3, p. 353-363, 2005. https://doi.org/10.1590/S0100-67622005000300002

DIAS FILHO, M. B. Degradação de pastagens: processos, causas e estratégias de recuperação. $2^{\mathrm{a}}$ ed. Belém: Embrapa Amazônia Oriental, 2005. 173 p.

GERON, L. J. V.; ZEOULA, L. M.; YOSHIMURA, E. H.; FRANCO, S. L.; CHIQUITELLI NETO, M.; PAULA, E. M.; SAMENSARI, R. B.; PERES, L. P. Ingestive behavior of Nellore heifers grazing receiving the supplement based on propolis or monensin. Semina: Ciências Agrárias, Londrina, v. 35, n. 4, p. 2047-2062, 2014. https://doi.org/10.5433/1679-0359.2014v35n4p2047

IPCC - INTERGOVERNMENTAL PANEL ON CIMATE CHANGE. Guidelines for National Greenhouse Gas Inventories. Institute for Global Environmental Strategies (IGES) for the IPCC, Kanagawa, Japan. 2006.

KANDA, K.; MIRANDA, C. H. B.; TAKAHASHI, M.; MACEDO, M. C. M. Nitrogen dynamics in agropastoral system of Brazil. Jircas Working Report, Tsukuba, v. 36, p. 19-23, 2004.

KÖPPEN, W. Climatologia: con un estudio de los climas de la tierra. México: Fondo de Cultura Económica, 1948. 478p.

MACEDO, G. G.; ZÚCCARI C. E. S. N.; PINTO DE ABREU, U. G.; NEGRÃO, J. A.; COSTA E SILVA, E. V. Human- animal interaction, stress, and embryo production in Bos indicus embryo donors under tropical conditions. Tropical Animal Health Production, Edinburgh, v. 43, n. 6, p. 1175-1182, 2011.

https://doi.org/10.1007/s11250-011-9820-6

MAGALHÃES, W. S.; MACEDO, R. L. G.; VENTURIM, N.; HIGASHIKAWA, E. M.; YOSHITANI JUNIOR, M. Desempenho silvicultural de espécies de Eucalyptus spp. em quatro espaçamentos de plantio na região noroeste de Minas Gerais. Floresta e Ambiente, Seropédica, v. 12, n. 2, p. 1-7, 2006.

NEVES, C. M. N. ; SILVA, M. L. N.; CURI, N.; MACEDO, R. L. G.; TOKURA, A. M. Estoque de carbono em sistemas agrossilvopastoril, pastagem e eucalipto sob cultivo convencional na região noroeste do Estado de Minas Gerais. Ciência e Agrotecnologia, Lavras, v. 28, n. 5, p. 1038-1046, 2004.

https://doi.org/10.1590/S1413-70542004000500010

NICODEMO, M. L. F.; SILVA, V. P.; THIAGO, L. R. L. S. Sistemas silvipastoris - introdução de árvores na pecuária do centro-oeste brasileiro. Campo Grande: Embrapa Gado de corte, 2004, 37 p. (Documentos, 146).

OLIVEIRA, T. K. ; MACEDO, R. L. G.; VENTURINI, N.; HIGASHIKAWA, E. M. Desempenho silvicultural e produtivo de eucalipto sob diferentes arranjos espaciais em sistema agrossilvipastoril. Pesquisa Florestal Brasileira, Colombo, n. 60, p. 1-9, 2009. (Edição especial).

PINDYCK, R. S.; RUBINFELD, D. L. Microeconomia. 8. ed. Madri: Pearson Educación. 2013. 768 p.

PORFÍRIO-DA-SILVA, V.; MEDRADO, M. J. S.; NICODEMO, M. L. F.; DERETI, R. M. Arborização de pastagens com espécies florestais madeireiras: implantação e manejo. Colombo - Brasil: Embrapa Florestas. 2009. 48 p.

PRIMAVESI, O. A pecuária de corte brasileira e o aquecimento global. São Carlos - Brasil: Embrapa Pecuária Sudeste. 2007. 42 p. (Documentos, 72). 
RIBEIRO, A. R. B.; ALENCAR, M. M.; NEGRÃO, J. A.; COSTA, M. J. R. P.; STARLING, J. M. C. Avaliação das respostas fisiológicas de bezerros zebuínos puros e cruzados nascidos em clima subtropical. Revista Brasileira de Zootecnia, Viçosa, v. 35, n. 3, p. 1146-1153, 2006. https://doi.org/10.1590/S151635982006000400028

RODRIGUES, R. N. Desempenho de novilhos Nelore a pasto no período das águas e terminados em confinamento. 2011. 49 f. Dissertação (Mestrado em Zootecnia), Faculdade de Zootecnia e Engenharia de Alimentos da Universidade de São Paulo, Pirassununga, 2011.

SANTOS, M. D. Efeito do espaçamento de plantio na biomassa do fuste de um clone hibrido interespecífico de Eucalyptus grandis e Eucalyptus urophylla. 2011. 140 f. Dissertação (Mestrado em Ciências Florestais), Faculdade de Ciências Agronômicas, Universidade Estadual Paulista, Botucatu, 2011.

SOUZA, W.; BARBOSA, O. R.; MARQUES, J. A. GASPARINO, E.; CECATO, U. BARBERO, L. M. Behavior of beef cattle in silvipastoral systems with eucalyptus. Revista Brasileira de Zootecnia, Viçosa, v. 39, n. 3, p. 677-684, 2010. https://doi.org/10.1590/S1516-35982010000300029

TORRES, C. M. M. E., JACOVINE, L. A. G., OLIVEIRA NETO, S. N. de, BRIANEZI, D., ALVES, E. B. B. M. Sistemas agroflorestais no Brasil: uma abordagem sobre a estocagem de carbono. Pesquisa Florestal Brasileira, Colombo, v. 34, n. 79, p. 235-244, 2014. https://doi.org/10.4336/2014.pfb.34.79.633

THUROW, J. M.; NABINGER, C.; CASTILHOS, Z. M. S.; CARVALHO, P.C. F.; MEDEIROS, C. M. O.; MACHADO, M. D. Estrutura da vegetação e comportamento ingestivo de novilhos em pastagem natural do Rio Grande do Sul. Revista Brasileira de Zootecnia, Viçosa, v. 38, n. 5, p. 818-826, 2009. https://doi.org/10.1590/S1516-35982009000500006

VIEIRA, A.; LOBATO, J. F. P.; CORRÊA, E. S.; TORRES JÚNIOR, R. A. A.; COSTA, F. P. Desenvolvimento e desempenho reprodutivo de novilhas Nelore criadas a pasto nos cerrados do Centro-Oeste brasileiro. Revista Brasileira de Zootecnia, Viçosa, v. 35, n. 1, p. 24-31, 2006. https://doi.org/10.1590/S151635982006000100024

WUBBLES, D. J.; HAYHOE, K. Atmospheric methane and global change. Earth-Science Reviews, Amsterdam, v. 57, n. 3-4, p. 177-210, 2002. https://doi.org/10.1016/S0012-8252(01)00062-9

ZANINE, A. M.; SANTOS, E. M.; FERREIRA, D. J. Grazing, leisure, rumination times and bite rate of bovine on pastures of different morphologic structures. Revista Eletrônica de Medicina Veterinária, Málaga, v. 7, n. 1, p. 1-10, 2006. 